\title{
Indonesian School Management Overseas (Case Study in Indonesia Kuala Lumpur School)
}

\author{
Matin ${ }^{1, a^{*}}$, Sugiarto ${ }^{1, b}$ \& Leni Pujiastuti 1 ,b \\ Postgraduate of Universitas Negeri Jakarta, Jakarta, Indonesia \\ matin@unj.ac.id \\ ${ }^{*}$ Corresponding Author
}

How to Cite : Matin, M., Sugiarto, S., Pujiastuti, L. (2020). Indonesian School Management Overseas (Case Study in Indonesia Kuala Lumpur School). International Journal for Educational and Vocational Studies, 2 (8), 679-684. DOI: https://doi.org/10.29103/ijevs.v2i8.2759

\section{ARTICLE HISTORY}

Received: 4 July 2020

Revised: 11 July 2020

Accepted: 17 July 2020

\section{KEYWORDS}

School Management;

Curriculum;

Students;

Educators;

\begin{abstract}
The purpose of this study is to describe and analyze the implementation of the management of the Kuala Lumpur Indonesian School in detail and thoroughly from the research subjects on the background of the study with existing characteristics. The case in this study is the application of management in the field of education which includes curriculum management, student management (students), personnel/member management, management of educational facilities and infrastructure, financial management, management of school relations with the community, and management of special services. This research uses a phenomenological qualitative approach with a case study design at the Kuala Lumpur Indonesia School located at No. 1, Lorong Tun Ismail, Kuala Lumpur, Malaysia, which consists of elementary, junior high, and high school. Data collection techniques are through observation, interviews, and documentation. Data collection techniques with triangulation, data analysis is inductive, and the results of qualitative research emphasize meaning rather than generalization. Based on the analysis of the data it was found that the supporting factors were that the Kuala Lumpur Indonesian School was already running and giving a good role in the implementation of the cultural diplomacy function in Malaysia and the School Financial Management was running well. When teachers whose contracts have expired and must return to Indonesia while substitute teachers have not yet arrived. In student management there is a problem of residence visas, teaching teachers not in accordance with the educational background result in professional competence.
\end{abstract}

This is an open access article under the CC-BY-SA license.

\section{INTRODUCTION}

Malaysia and Indonesia have locations that are close to each other, sometimes it is often debated about Indonesian wealth which is often claimed by Malaysia. Through cooperation in the field of education, especially at the Kuala Lumpur Indonesian School, holding cultural diplomacy by holding a collaboration that contains exhibitions/shows that showcase the richness of authentic Indonesian culture by involving students of the Kuala Lumpur Indonesian School, so that the Malaysian community knows the culture and riches of Indonesia.

The challenges at Indonesian Schools Abroad are that the traditions and culture of the local country are different from Indonesian culture, so the obstacles faced by SILN in educating the character of the nation's children are quite heavy. In connection with the application of school management in the Kuala Lumpur Indonesian School to be discussed in this study, it consists of curriculum management, student management, management of educators and education personnel, mana- gement of school and community relations, and financial management. First to be discussed is curriculum management, as a basis for implementing learning must be able to answer the needs of students. The curriculum compiled by the government is something that must be developed and adjusted to the potential that exists in the region if curriculum development is carried out following the provisions it will have a positive impact on school quality. After the school has done good curriculum management, the other thing that must be considered is student management is concerning the service to the needs of students at school. A series of student activities that must be carried out by schools is to conduct a selection to get quality students and the acceptance of new students using certain criteria. The activity of developing students' interests and talents that are used as a vehicle for digging into their potential needs to be carried out optimally. Guidance and coaching for students so that there is awareness for the creation of a good school atmosphere. 
In addition to curriculum management and student management, the management of educators and education staff is an activity that must be carried out starting from the teaching and education staff entering the organization. So that all activities can run smoothly, then as personnel or employees who work in an agency must know the obligations and rights as employees, so that the implementation of the tasks will be balanced. This will affect whether or not the quality of the work of the personnel. For example, an elementary school teacher who knows what his duties and obligations are, he will be able to easily carry out his role as a teacher and as personnel of an agency.

Management of school relations with the community relates to student guardians and residents around the school, as well as government and private institutions that are around the school. This relationship between the community and the school are mutually beneficial. For example, schools get criticism and suggestions from the community if there is indeed a shortage of schools, and schools can accept and fix them or the school asks for help and support when there are certain activities. It can also express an opinion between people and school and solve problems. The focus of research on curriculum management, student affairs, educators and education personnel, management of the Indonesian school relation Kuala Lumpur with surrounding communities, and financial management of the Indonesian school Kuala Lumpur.

\section{LITERATURE REVIEW}

Daft (2010) explains that: "Management is the attainment of organizational goals effectively and efficiently through planning, organizing, leading and controlling organizational resources. That means management is the achievement of organizational goals effectively and efficiently through planning, organizing, directing, and controlling organizational resources. Whereas Fattah (2011) said that "Management is defined as the process of planning, organizing, leading and controlling organizational efforts with all its aspects so that organizational goals are achieved effectively and efficiently."

Terry (1974) said that "Management is a district process consisting of planning, organizing, actuating and controlling performed to determine and accomplish stated objectives by the use of human beings and other resources". Management is a particular process that consists of planning, organizing, moving, and supervising carried out to determine and achieve the goals set by using both personal and material resources. People and objects to achieve the desired goals.

Muhaimin (2011) said that "Management is a process of using resources effectively to achieve certain goals or objectives". Rohiat (2010) states that "The management process involved the main functions displayed by a manager or leader, namely: planning (planning), organizing (organizing), leadership (leading), and supervision (controlling)". Therefore it can be concluded that management is a set of management processes as components that are in it to achieve the goals set.

Management can be used for various organizations and various fields, including schools. Sagala (2011) said that "School management is the process and agency that leads and guides the implementation of schoolwork as an organization and realizes the educational goals and objectives of the school that have been set". Rohiat (2010) stated that "School management is managing the resources owned by schools or organizations which include people, money, methods, materials, machines, and marketing which are carried out systematically in a process".

Based on the description above it can be concluded that school management is defined as the process of utilizing school resources. Utilization of these resources through activities management functions. These functions include the functions of planning, organizing, mobilizing, and controlling more effectively and efficiently with all its aspects using all available potential to achieve organizational goals effectively and efficiently as well as quality school productivity.

Syaiful (2009) states that "School management aims to create better work procedures in four ways, namely: increasing efficiency in the use of resources and assigning staff, increasing professionalism of teachers and education staff in schools, the emergence of new ideas in the curriculum implementation, the use of learning technology, and the use of learning resources, and improving the quality of community and stakeholder participation". Whereas Daryanto (2013) states that "School management is carried out having a specific goal so that: First at every type and level of education there is the effectiveness of production. The graduates can do at the level of education above, can work through knowledge and skills. Second, to achieve efficient use of resources and funds, there is no waste of time, energy or money, and others. Third, the graduates can adjust to life in society, and Fourth, the creation of job satisfaction for each member of the school community. For this reason, a healthy school organization climate needs to be built".

The principles that must exist in carrying out school management are efficient, effective, management of existing resources, prioritizing management tasks, good cooperation, and effective leadership. All these principles must be owned and guided properly by a manager so that the implementation of school management can run perfectly.

\section{Curriculum Management}

Curriculum management is a curriculum as an educational design that has a very strategic position in all aspects of educational activities. Considering the important role of the curriculum in the education and development of students' lives, curriculum development cannot be done without using a solid and strong foundation (Ornstein and Hunkins 1998). Whereas Zais 
(1976) states that "The curriculum can be understood as a subject program, such as English, algebra, history, economics, and others. In other words, the curriculum includes a list or title of subjects delivered by the school. Another view states that the curriculum is the content of certain subjects in the program or data and information recorded in guiding students through notebooks that are needed and provided in the learning plan".

Tulus (2004) states that "Principles in curriculum development are as follows: (1) The desired goals must be clear, the more operational the objectives, the more easily visible and the more precise the programs developed to achieve the objectives, (2) The program must be simple and flexible, (3) Programs developed and developed must be in accordance with the stated objectives. (4) The program developed must be comprehensive and its achievements must be clear. (5) There must be coordination between the program implementing components in schools". In school management, it is necessary to divide tasks to support the curriculum, for example by compiling a calendar of school activities and lesson schedules, learning evaluations, and norms of kindness.

Triwiyanto (2015) suggests the curriculum management cycle which consists of the following four stages:

a. The planning stage; includes steps as 1) needs analysis; 2) formulating and answering philosophical questions;

3) determine curriculum design; 4) create a master plan: development, implementation, and assessment.

b. Development stage, including the steps: 1) rational formulation or rationale; 2) formulation of vision, mission, and goals; 3) determining the structure and content of the program; 4) selection and organization of material; 5) organizing learning activities; 6) selection of sources, tools, and learning tools; 7) determining how to measure learning outcomes.

c. The implementation phase includes the following steps: 1) preparation of the learning plan; 2) translation of material; 3) determining learning strategies and methods; 4) providing learning resources, tools, and facilities; 5) determining the ways and tools for evaluating learning processes and outcomes and 6) setting the learning environment.

d. Assessment stage; to see the strengths and weaknesses of the curriculum developed both formative and summative assessment forms. Curriculum assessment can include context, input, process, product (CIPP). Product assessment focuses on measuring process achievement at the end of the program (synonymous with summative evaluation). The term evaluation usually refers to the process of making an assessment (Arendes, 2004).

e. Determine a value or decide well.

\section{Student Management}

Student management aims to regulate various activities in the student field so that learning activities in schools can run smoothly, orderly, regularly, and achieve the goals of school education. That need to be considered in managing students is as follows: student attendance at school and the problems faced related to it, acceptance, orientation, classification, the appointment of class students and study programs, evaluation, and progress of learning outcomes, supervision programs for students who have abnormalities, such as exceptional teaching, improvement and teaching, student discipline control, counseling and counseling programs, health and safety programs, and personal, social and emotional adjustment.

\section{Management of Educators and Educational Personnel}

Pidarta (2011) said that "Personnel is all members of the organization who work for the interests of the organization, that is, to achieve predetermined goals. Personnel from educational organizations include teachers, employees, and student representatives. Including education managers who may be held by some teachers". Personnel management is the part of management that pays attention to people in the organization, which is one of the management system sub-chapters. Attention to these people is enough to recruit, place, train, develop, and improve their welfare which is said to be as happy as the personnel management function (Filppo, 1984).

\section{Management of School Relations with the Community}

Munifah (2009) states that "Public relations is a translation of relationships with the society. In this case the community is associated with factors of mutual interest. So the activities are aimed at the internal public (employees) and public extern (people outside the organization)".

\section{Financial Management}

Sources of funding for financial education and financing at the level of the education unit, in general, are obtained from subsidies from the central government, regional governments, student fees, and community contributions. As far as recorded in the School Revenue and Expenditure Budget Plan (RAPBS), most education costs at the school level come from the central government, while private schools come from students or foundations (Supriadi, 2003).

\section{METHODS}

This research uses a phenomenological qualitative approach with a case study design. The qualitative approach was chosen because the object of this research was in the form of a process or activity or a person's actions, namely about education management, school management, the object of research was in a natural condition, and the data revealed were not numbers, but words, sentences, paragraphs, and documents. The object of this study was not manipulated or given certain treatment so that it is in a natural condition. The data is collected through interviews and observations in the field, 
then analyzed inductively. Based on these characteristics, this study is more appropriate to use a qualitative approach.

The social event in this study is the effort of the management of the Kuala Lumpur Indonesian School in preparing a plan and implementing it to achieve the stated goals and carrying out the field of management in the school and reporting the results to the parties concerned with the holding of the Kuala Lumpur Indonesian School. Management activities are social events where managers carry out activities with or through others to achieve a goal. The degree of implementation cannot be measured with exact numbers and it is difficult to state explicitly or wrongly, so this research is more appropriate using a phenomenological approach.

This research data is in the form of the opinion of the Kuala Lumpur Indonesia School management about how to manage school management. School management will be achieved maximally if the implementation of the management sector in a school can run according to the expectations of various parties including parents of students, and teachers, the central government, and students themselves. The research location is in the Kuala Lumpur Indonesia School located at No. 1, Lorong Tun Ismail, Kuala Lumpur, 50480 Kuala Lumpur, Wilayah Persekutuan Kuala Lumpur, Malaysia is a one-stop school consisting of 3 levels of education consisting of elementary, junior high, and high school. The learning activities are carried out for 5 full days based on the title of the study, which examines school management at the Indonesian School in Kuala Lumpur in the academic year 2019/2021. Data collection techniques used in this study were observation techniques, interview techniques, and documentation.

The process of data analysis based on an interactive model developed by Miles and Huberman (1997) will be described as follows:

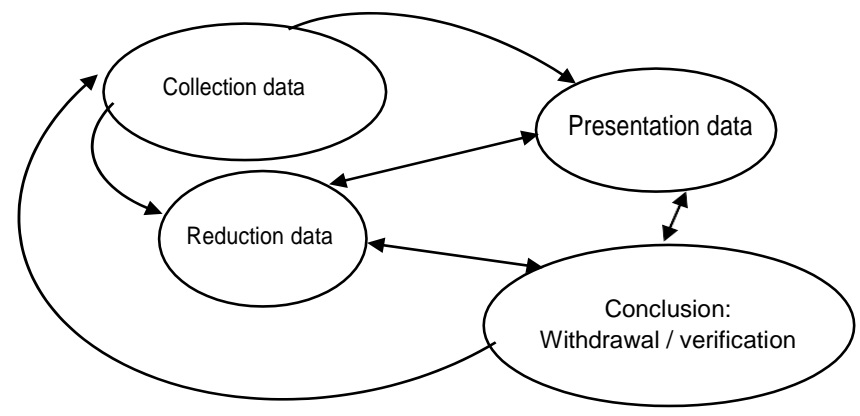

Figure 1. Process of data analysis based on an interactive model developed by Miles and Huberman

Based on the above opinion that as a key instrument of data collection, researchers carry out reduction, phenomenological and data reduction, and transcendental reduction. The phenomenological reduction is done by researchers to free themselves from subjective assessments of phenomena, not the subjective opinion of researchers. Data reduction is done by freeing themselves from theories, scientific propositions, or traditional doctrines that can pollute the purity of data. On the reduction of researchers looking for the essence of the phenomenon of school management in the Kuala Lumpur Indonesian School.

\section{RESULTS AND DISCUSSIONS}

\section{Curriculum Management}

The curriculum at the Indonesian School in Kuala Lumpur is based on a national curriculum and enriched with international curriculum content. While the implementation of the curriculum is outlined in various activities including curricular, extracurricular, and co-curricular. Schools make a breakthrough in teaching and learning activities in addition to face-to-face in the classroom, also implementing a distance learning system called the Distance Teaching and Learning Program (PBMJJ). PBMJJ SIKL began to be built in 2019 using the Learning Management System (LMS) platform on a server that was owned by the school. In this PBMJJ System, all classy learning content from each elementary, junior high, and high school level has been completed by classroom teachers and SIKL subjects by implementing communicative distance learning.

The evaluation of the Kuala Lumpur Indonesian School curriculum is routinely evaluated according to the condition of school resources, the development of science and technology, and the Changes in the global education paradigm due to the existence of SIKL in Malaysia so that it must adjust the global education paradigm. Some adjustments have been made, including adjusting the curriculum structure by adding subjects that are Computer Science \& Robotic, English and Gamelan Arts and Angklung.

\section{Student Management}

New student admission activities consist of determining the requirements received, new admissions committee, and new student orientation. The admission process begins with prospective students registering online and then the parents fill out the form provided and upload all the required documents. After that, the parents will get an answer via email, if the requirements are met and the quota is still available then the parents are asked to come to school with all the original documents for verification. Furthermore, if students are accepted, continue with the introduction to the school environment.

\section{Management of Educators and Educational Personnel}

In the recruitment of educators and education staff at the Indonesian School in Kuala Lumpur, the role is to determine the formation of educators and the educational requirements needed and later the formation will be submitted to the Ministry of Education and Culture (Kemdikbud). So the task of the school is to analyze the needs of educators and the education needed for schools. Based on the phrase Mr. Principal of the Indonesian School in Kuala Lumpur it can be understood that in the 
recruitment activities where every educational staff received must have a high level of competence and skills with the following criteria: the teacher is able to teach multi-level and multi-subject well, good at English though not an English teacher, can operate a computer well, and is able to write school articles well. Whereas the provision of education personnel is an activity to meet the needs of education personnel in an educational institution. For this purpose, the selection is needed through oral, written, and practical examinations.

\section{Management of School Relations with the Community}

Based on the results of the study, it was found that the planning process of the school relations program with the community at the Kuala Lumpur Indonesian School had been carried out systematically. The first activity in planning a school relations program with the community is an analysis of the needs of the school, then proceed with the development of the program, as well as determining the person in charge for each activity. The first step to establishing communication with the community is to determine what public relations activities are. To plan a program of school principals' activities with the Education and Cultural Attaché in Malaysia, the vice-principal, and the school committee together and communicate well with each other in determining what activities will be carried out. In implementing the management of school relations with the community the school committee plays an active role in supporting school programs. Communication and coordination between schools and committees complement each other, even in determining the annual school budget plan. After that, the principal informs the results to all teachers and school staff and students.

\section{School Financial Management}

Based on the results of interviews and document review, the source of funding at the Indonesian School in Kuala Lumpur comes from contributions of Education Development Donations from each student, government assistance, and assistance from community organizations for students who cannot afford tuition fees. Funding in teaching and learning activities is the key to success in learning because with the availability of sufficient funds can support the entire process of teaching and learning activities to be smooth. One source of school funding is derived from the tuition fees of each student, in this case, the school agrees with the parents related to the withdrawal and the amount of the SPP.

\section{CONCLUSION}

Curriculum planning at the Kuala Lumpur Indonesia School has been going well. However, the implementation of curriculum management, there are still problems faced by schools namely there is a vacancy of certain subject teachers when teachers who have finished their contracts and must return to Indonesia while substitute teachers have not yet come. Furthermore, in terms of evaluating school curriculums have carried out under the provisions i.e.a daily assessment, midterm assessment, end of semester assessment, grade promotion assessment. The admission of new students at the Indonesian School in Kuala Lumpur is quite easy and simple. Registration is done online using the new Google Form and after fulfilling the student requirements and then parents will be called to school by bringing the original documents needed. Extracurricular activities are also very diverse which aims to improve student achievement. However, the obstacle is that schools cannot take part in competitions or academic competencies such as the Science Olympics held both in Malaysia and nationally in Indonesia such as the National Science Olympiad (OSN), the National Student Sports Olympiad (O2SN) and the National Student Art Competition (FLS2N). Invitation to competitions and competitions from Malaysian schools or educational institutions that are often accepted by schools is for Non-Academic activities. Students also experience obstacles that greatly interfere with the learning activities of some students, namely the problem of residence visas. Malaysian immigration rules stipulate that students whose parents are not permanent residents, professional residence visa holders, student visa holders are required to return to Indonesia. Even though students are in the middle of the semester or for students in-class examinations are awaiting exam time.

\section{Management of Educators and Educational Personnel}

In the process of appointing educators and education personnel at the Indonesian School in Kuala Lumpur, it still does not fit the ideal situation in the field. Teachers assigned to SIKL are teachers who are required to be able to teach multi-subject and multi-level, but at the time of appointment, the requirements and tests are carried out only under their field of education. In reality, teachers are required to be able to teach outside the field of study they have, in the process of appointing teachers, teachers must be mentioned with dislike what fields of study should be mastered by the prospective teacher. This will be important because teachers who master the material well will have a good impact on their students. But in this case, the teacher was able to prove that they succeeded in teaching several fields of subjects and multi-level well, it can be seen that teachers at the Indonesian School of Kuala Lumpur have succeeded in increasing their student competence in the academic field as evidenced by the results of high school student test scores. Besides, there are still several teachers who have not been certified, so that it affects the professionalism of these teachers. Whereas the framing and supervision of educators and education personnel have been running smoothly because the school principal and Atdikbud have performed their roles optimally. The planning of the school-community relations program at the Kuala Lumpur Indonesia School has been going well realized by always involving various parties including the Indonesian Education and Culture Attaches in Malaysia, the teacher council, committees, student guardians, and community leaders. The financial 
planning of the Indonesian School in Kuala Lumpur has been going well, the school principal has coordinated and involved various parties or with stakeholders related to school finance.

\section{REFERENCES}

Amirin, Tatang, et al. (2010). Manajemen Pendidikan. Yogyakarta: UNY Press.

Arikunto, Suharsimi. \& Yuliana, Lia. (2008). Manajemen Pendidikan. Yogyakarta: Aditya Media.

Bafadal. (2004). Manajemen Perlengkapan Sekolah Teori Dan Aplikasinya. Jakarta: Bumi Aksara.

Basrowi \& Suwandi. (2008). Memahami Penelitian Kualitatif. Jakarta: Rineka Cipta

Bell, Les. (2002). Strategic Planning And School Management: Full Of Sound And Fury, Signifying Nothing?. Journal of Educational Administration.

Burrup, Percy. (1962). Modern High School Administration. New York: Harper Brother Publisher.

Danumihardja, Mintarsih. (2004). Manajemen Keuangan Sekolah. Jakarta: Uhamka Press.

Daryanto \& Darmiatun. (2013). Implementasi Pendidikan Karakter Di Sekolah. Yogyakarta: Gava Media.

Daft, Richard L. (2010). Management. New Jersey: Prentice Hall.

Edwin, Filppo. (1984). Manajemen Personalia. Jakarta: Erlangga.

Fayol, Henry. (1985). Industri Dan Manajemen Umum, Terj. Winardi, London: Sir Isaac and Son.

Gutman, Leslie Morrison, \& Mcloyd, Vonnie C. (2000). Parents' Management of Their Children's Education within the Home, At School, And In the Community: An Examination of African-American Families Living In Poverty. The Urban Review, 32(1), 1-24.

Hamidi. (2004). Metode Penelitian Kualitatif. Malang: UMM Pres.

Handayaningrat, Soewarno. (1982). Pengantar Studi Ilmu Administrasi Dan Management. Jakarta: PT Inti Idayu Press.

Harsono. (2008). Model-Model Pengelolaan Perguruan Tinggi. Yogyakarta: Pustaka Pelajar.

Indrafachrudi, Soekarto. (1994). Bagaimana Mengakrabkan Sekolah Dengan Orang Tua Murid Dan Masyarakat. Malang: IKIP Malang.

John, Echol \& Hasan, Shadily. (1996). Kamus Inggris Indonesia. Jakarta: PT Gramedia.

Koontz \& O Donnel (2006). Principles of Management and Analysis of Management Function, 5th Ed. Mc Graw Hill: Booy Coy.

Manullang, Marihot. (2006). Manajemen Personalia. Yogyakarta: Gajah Mada University Press.

Maryadi, Dkk. (2010). Pedoman Penelitian Skripsi FKIP. Surakarta: BP-FKIP UMS.

Miles, Mathew \& Michael,Huberman. (1992). Analisis Data Kualitatif Buku Sumber Tentang Metode-Metode Baru. Jakarta: UIP.
Moleong, Lexy. (2004). Metodologi Penelitian Kualitatif. Bandung: PT. Remaja Rosdakarya.

Mulyasa, Enco. (2011). Manajemen Berbasis Sekolah (Konsep, Strategi Dan Implementasi) Cetakan Ketigabelas. Bandung: PT. Remaja Rosdakarya.

Mulyono. (2008). Manajemen Administrasi Dan Organisasi Pendidikan. Yogyakarta: Ar Ruzz Media Group.

Munifah. (2009). Manajemen Pendidikan Dan Implementasinya. Kediri: STAIN

Nawawi, Hadari \& Martini, Hadari. (1992). Instrumen Penelitian Bidang Sosial. Yogyakarta: Gadjah Mada University Press

Notoatmodjo, Soekidjo. (1998). Pengembangan Sumber Daya Manusia. Jakarta: Rineka Cipta.

Nurkolis. (2006). Manajemen Berbasis Sekolah. Jakarta: PT. Gramedia Widia Sarana Indonesia.

Ornstein, Allan \& Hunkins, Francis. (1998). Curriculum: Foundations, Principles and Issues. Boston: Allyn and Bacon

Purwanto, M Ngalim. (1987). Administrasi Dan Supervisi Pendidikan: Remadja Karya.

Rohiat. (2010). Manajemen Sekolah Teori Dasar Dan Praktik, Bandung: Aditama.

Richard L Arends. (2004). Learning To Teach, New York: Mcgraw Hill

R.Terry, George. (2006). Prinsip- Prinsip Manajemen. Jakarta: Bumi Aksara.

Saifuddin, Azwar. (2007). Metode Penelitian. Yogyakararta: Pustaka Pelajar.

Saudagar \& Idrus. (2011). Pengembangan Profesionalitas Guru. Jakarta: Gaung Persada.

Siagian, Herbangan. (1989). Administarsi Pendidikan Suatu Pendekatan Sistemik. Semarang: PT Satya Wacana.

Soenarya, Endang. (2000). Pengantar Teori Perencanaan Pendidikan Berdasarkan Pendekatan Sistem. Yogyakarta: Adicita Karya Nusa.

Soewarno, Handayaningrta. (1982). Pengantar Studi Ilmu Administrasi Dan Management. Jakarta: PT Inti Idayu Press.

Sulistyorini. (2009). Evaluasi Pendidikan Dalam Meningkatkan Mutu Pendidikan,Yogyakarta: Teras

Supriadi. (2003). Satuan Biaya Pendidikan Dasar Dan Menengah. Bandung: PT. Remaja Rosda Karya.

Suriansyah, Ahmad. (2001). Hubungan Sekolah Dengan Masyarakat. Diktat Bahan Kuliah Pada Program Studi Administrai Pendidikan, FKIP Unlam. Banjarmasin: FKIP Unlam.

Suryosubroto. (2004). Manajemen Pendidikan Di Sekolah. Jakarta: PT. Rineka Cipta.

Usman, Husaini. (2006). Manajemen: Teori, Praktik, Dan Riset Pendidikan. Jakarta: Bumi Aksara.

Wahyosumidjo. (2008). Kepemimpinan Kepala Sekolah. Jakarta: Rajawali Pers.

Zais (1976). Curriculum Pripnciples And Founddation. Newyork: Harper \& Row Publisher. 